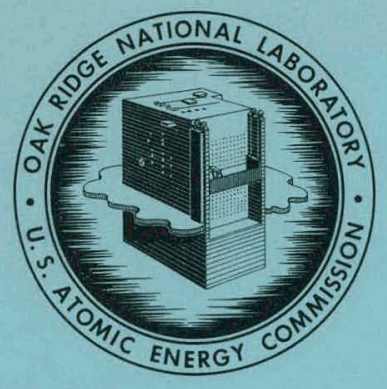

OAK RIDGE NATIONAL LABORATORY

operated by

UNION CARBIDE CORPORATION

NUCLEAR DIVISION

for the

U.S. ATOMIC ENERGY COMMISSION

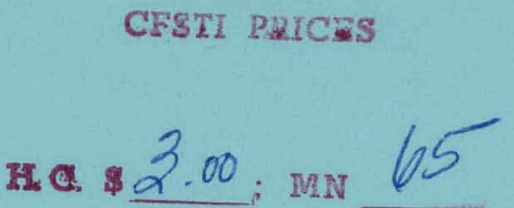

ORNL - TM- 1876

COPYNO. - 41

DATE - May 9, 1967

\title{
APPLICATION OF HIGH PRESSURE ION EXCHANGE COLUMN TO THE SEPARATION OF TRIVALENT ACTINIDES AND LANTHANIDES
}

\author{
S. R. Buxton and D. O. Campbell
}

\section{ABSTRACT}

A high-pressure ion exchange system has been tested by separating neodymium from praseodymium, a problem representative of those presented by the trivalent actinide separations, by chromatographic elution with a-hydroxyisobutyric acid from Dowex 50 resin. A high-pressure pump is used to force solutions at a high flow rate through a column which contains resin of small particle size. The high pressure permits greater freedom in the selection of operating parameters such as resin particle size, column length, and flow rate. The system has the capability of accomplishing anything that can be accomplished by any conventional ion exchange column system, but with much higher flow rates and, therefore, in much less time. Deleterious effects of radiation damage from high-activity level materials are accordingly minimized. Operation has been unusually smooth, and essentially no problems have arisen.

Quantitative separations have been obtained routinely with flow rates up to $25 \mathrm{ml} \mathrm{cm}$
$\min ^{-1}$, much higher than are normally used. The experiments were done on a scale generally of the order of $100 \mathrm{mg}$ of rare earth rather than the more usual tracer level. The degree of separation could be controlled from some overlap of the elution bands to complete separation, by controlling the eluent concentration. In one case, seven column volumes between the neodymium and praseodymium bands contained no detectable rare earths. With greater rare earth loadings, a more dilute eluent was required to yield the same degree of separation; alternatively, a larger column could be used with larger loadings. Operation at elevated temperature is generally desirable because the pressure drop is lower at a given flow rate, but temperature appears to have only a minor effect on kinetics as indicated by band tailing. Elution bands are not symmetrical, showing a slow, nearly linear increase in concentration followed by an abrupt decrease.

NOTICE This document contains information of a preliminary nature and was prepared primarily for internal use at the Oak Ridye Nalional Laboratory. It is subject to revision or correction and therefore does not represent a final report.

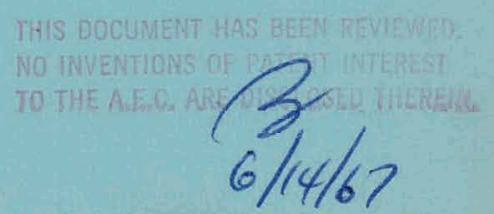




\section{DISCLAIMER}

This report was prepared as an account of work sponsored by an agency of the United States Government. Neither the United States Government nor any agency Thereof, nor any of their employees, makes any warranty, express or implied, or assumes any legal liability or responsibility for the accuracy, completeness, or usefulness of any information, apparatus, product, or process disclosed, or represents that its use would not infringe privately owned rights. Reference herein to any specific commercial product, process, or service by trade name, trademark, manufacturer, or otherwise does not necessarily constitute or imply its endorsement, recommendation, or favoring by the United States Government or any agency thereof. The views and opinions of authors expressed herein do not necessarily state or reflect those of the United States Government or any agency thereof. 


\section{DISCLAIMER}

Portions of this document may be illegible in electronic image products. Images are produced from the best available original document. 
LEGAL NOTICE

This report was prepared as an account of Govermmenl spansored work. Neither the United States, nor the Commission, nor any person acting on behalf of the Commission:

A. Makes any warranly or representation, expressed or implied, with respect to the accuracy, completeness, or usefulness of the information contained in this report, ur that the use of any information, apparatus, method, or process disclosed in this report may not infringe privately owned rights; or

B. Assumes any liabilities with respect to the use of, or for damages resulting from the use of any information, apparatus, method, or process disclused in this report.

As used in the above, "person acting on behalf of the Commission" includes any employes or contractor of the Commission, or employee of such contractor, to the extent that such employee or contractor of the Commission, or employee of such contractor prepares, disseminates, or provides access to, any information pursuant to his employment or contract with the Commission, or his employment with such contractor. 


\section{PAGES 1 to 2 WERE INTENTIONALLY LEFT BLANK}




\section{CONTENTS}

$\begin{array}{lc}\text { Abstract } & \text { Page } \\ \text { Introduction } & 1 \\ \text { Experimental } & 4 \\ \text { Reagents } & 5 \\ \quad \text { Analyses } & 8 \\ \text { Results and Discussion } & 8 \\ \text { Effect of Rare Earth Loading } & 9 \\ \text { Effect of Flow Rate } & 9 \\ \text { Effect of Temperature } & 13 \\ \text { Effect of Eluent Concentration } & 15 \\ \text { Effect of Column Orientation } & 15 \\ \text { Loading Tests } & 18 \\ \text { Plans for Additional Work } & 18 \\ \text { References } & 22\end{array}$




\section{INTRODUCTION}

Among the more difficult chemical separations are the intra-group separations of trivalent lanthanide and actinide elements. The conventional procedures are ion exchange chromatography utilizing cation exchange resin and an anionic complexing agent, ${ }^{-7}$ anion exchange, resin and a concentrated salt solution, $8-11$ or in some cases extraction chromatography. $12-14$ Good separations are readily achieved with tracer concentrations of the metals, but problems are encountered when the procedures are applied to macro amounts of material and, especially, to high levels of radioactivity such as are encountered in the large scale separation of $242 \mathrm{Cm}$ from $241 \mathrm{Am}$ and the projected separations of californium and the heavier elements. $5,15,16$ Generally, two problems predominate. These are radiation damage to the resin, especially during the loading stage when high concentrations are obtained on the resin for appreciable lengths of time, and gassing in the column resulting from radiolysis and causing uncontrolled flow rates, channeling, and sometimes separation of the resin bed. The former may prevent elution of the column; the latter smears the bands, diminishing the separation.

Chemical separations which are perhaps even more difficult than these are encountered in the biochemistry field, and these are generally attacked by using quite long columns containing very fine resin. Flow rates are necessarily low, and elutions may take days. Recently a high-pressure ion exchange system which greatly alleviates these problems has been developed at ORNL for analysis of body fluids. ${ }^{17}$ Briefly, a high-pressure pump is used to force the solutions through the column; a pressure drop of several thousand pounds per square inch across the column is entirely practicable. The high-pressure drop gives the designer much more leeway in selecting operating parameters than he has with the usual column operating with a pressure drop two or three orders of magnitude smaller. For example, he may use a longer column of smaller cross-sections, resin with a smaller particle size, a higher flow rate, or any combination of these. More than one hundred different compounds have been separated from body fluids in a single elution with such a system.

This high-pressure system appears to be particularly suited to the separation of high-radiation level actinides, since it permits the minimization of both of the problems described above. It is practical to use both a smaller resin particle size and a higher flow rate, thus alleviating any kinetic problems whether they arise from chemical or physical factors. As a result, a given amount of feed can be loaded on a column in less time, which reduces the radiation damage problem. Similarly, the elution can be conducted at a much higher flow rate. Secondly, since the column is under pressure, bubble formation from radiolytic products is eliminated throughout most of the column because of the increased solubility of gasses in solution at higher pressures. Even if the gas solubility is exceeded, the bubbles are much smaller because of the higher pressure. The pressure does drop along the length of the column, and gassing may occur near the bottom, but by this time the separation has been 
largely obtained. Further, it is possible to prepare a column so that a substantial part of the pressure drop occurs at the very bottom, thus eliminating gassing throughout practically the entire column length, or to apply back pressure.

We fully realize that the mere mention of the words, "high pressure" and "highradiation level," in the same report almost reflexively leads to the question of safety. The fact is, however, that the consequences of a leak or rupture in the high-pressure system are no greater than in conventional systems, because care is taken to prevent large pockets of pressurized gas and the probability of such an event is smaller because the system is designed to contain the pressure. Damage following rupture is the result of both the pressure and the volume through which. the pressure expands, in this case the volume of gas compressed plus the change in volume of elastic materials. in the system. Although the pressure is high in this system, there is a very small volume of gas, and it can be made practically zero by proper equipment design and operation. All components under pressure are stainless steel (far below any limiting stress), and water is relatively incompressible, so there is practically no change in volume upon pressure release. Such is not the case for systems using air pressurization or plastic tubing under pressure. Finally, since the sytem is designed for much higher pressures than those of normal operation, even a rather fast chemical reaction in the column would very likely only result in expulsion of the liquid from the column into the receiver. In addition, a rupture disc or pressure relief valve vented to a large receiver could be used.

As a result of these considerations an experimental program has been initiated to adapt the high-pressure ion exchange column to actinide and lanthanide separations in glove box and hot cell applications. The work reported here is concerned with a typical case, the separation of neodymium and praseodymium by chromatographic elution from cation exchange resin with a-hydroxyisobutyric acid. The system is clearly applicable to any such ion exchange system, however, with the same advantages over the more conventional equipment. This system appears to be advantageous for any separation problem in which there is some desire to decrease the required time. At the same time, separations are potentially better because of the use of fine resins which results in better kinetics and more uniform flow. These preliminary data are being reported now because considerable. interest has arisen in the utilization of this system.

\section{EXPERIMENTAL}

A schematic diagram of the high-pressure ion exchange column is shown in Fig. 1. A positive displacement pump (Accu-Flow Model No. AP-1M-2 made by Spinco: Division of Beckman Instrument Company) was used to pump the solutions. Flow rates can be varied from near zero to $2.6 \mathrm{ml} / \mathrm{min}$ by adjusting the stroke length; the volume pumped is less than $0.1 \mathrm{ml}$ per stroke. A speed changer is available 
ORNL DWG 67-3655 RI

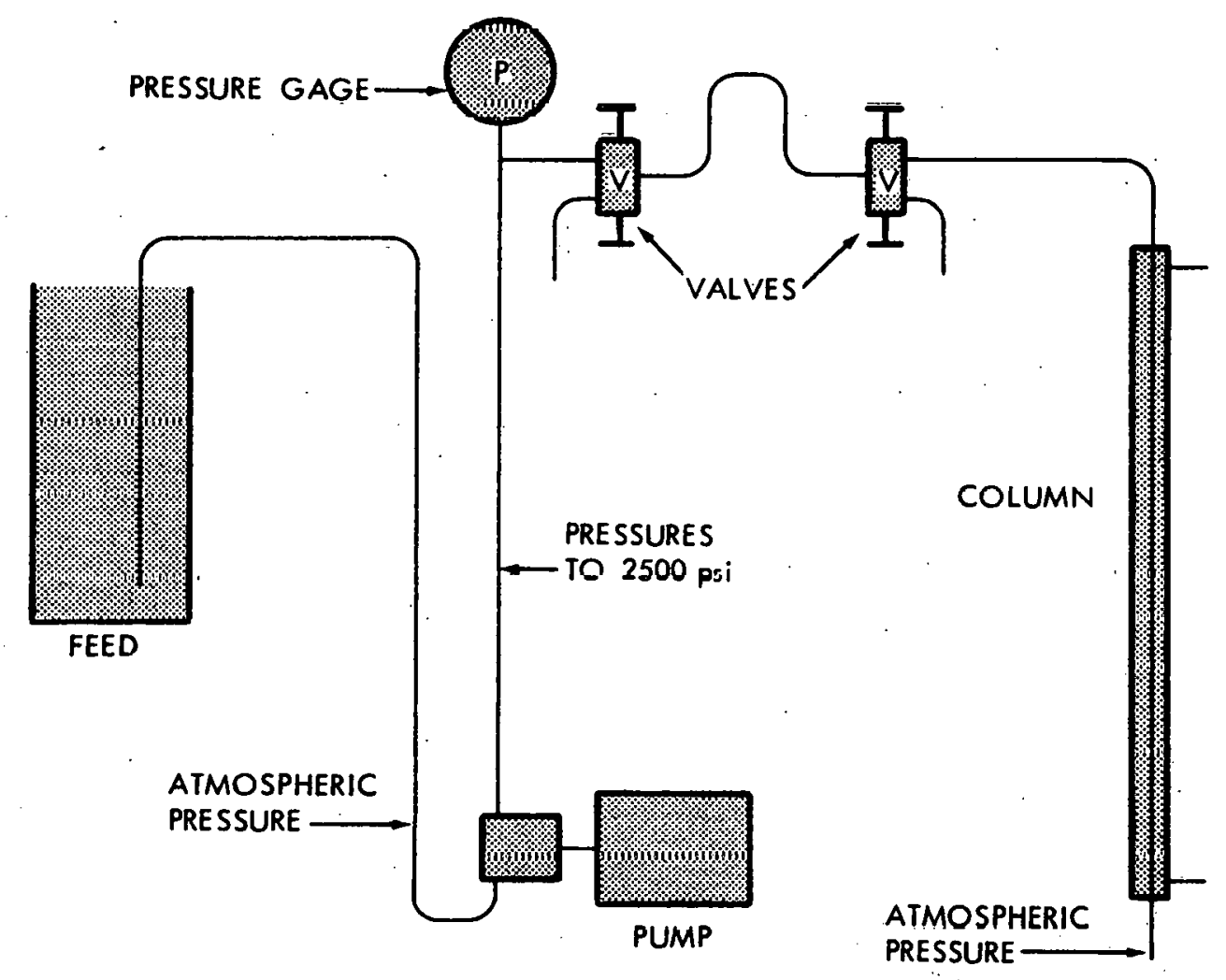

Fig. 1. High-Pressure' Ion Exchange System. 
which gives a four-fold increase in pumping rate by quadrupling the frequency. of piston travel. The pump is rated to $1000 \mathrm{psi}$, but it has been used routinely at pressures up to 1700 psi and occasionally to 2500 psi, with no serious difficulties. A rupture disc or pressure relief valve can be used to protect the pump. A rupture disc was used during the first few runs, but no protective device was used subsequently.

No.leakage occurred during some $300 \mathrm{hr}$ of operation under pressure, including about 35 elutions. The pump operated excellently until the speed-changer was added to permit higher flow rates. Subsequently, several minor problems developed, including a leak which was eliminated by replacement of an O-ring seal. These caused no serious trouble with direct operation, but they would have stopped operation in a hot cell.' For hot cell use certain modifications will be necessary, including a more accessible mechanism for operating the speed-changer and a better flexible coupling between the motor and the pump. Seal replacement would be impossible in a hot cell but would probably be possible in a glove box.

Even though a bubble trap was not used in the line to the pump, little trouble due to bubbles was encountered. (Bubbles might be trapped in the check valves, causing a decrease in pumping rate.) During this work abnormally low flow rates were encountered only two or three times, and these were quickly cleared by venting the high-pressure side of the pump (but not the column) and pumping at a high-flow rate for a short time. If high-activity level solutions pass through the pump, gassing may cause some trouble, and it may be necessary to degas the solutions just before they go to the pump.

All lines were 1/8-in. stainless steel, 35-mil wall. The sample line between the two valves (Fig. 1) was used primarily to load the column with the rare earth feed. Two milliliters of solution containing the desired amount of rare earths was injected into this line with a syringe, and then pumped onto the column. This method was used to prevent any rare earths from being held up in the pump packing or the line to the pressure gauge, since such material might find its way back into the eluent and result in apparent tailing of the elution bands. Two loadings were made through the pump, and there was some evidence.for such tailing in one case. In the other, care was taken to rinse out the lines after loading, and no tailing was apparent.

The only gas volume in this system was associated with the pressure gauge. This could be decreased from some $10 \mathrm{ml}$, depending on the particular gauge used, to essentially 0 by filling the gauge with water. The pressure pulsed with each stroke of the pump even with gas in the pressure gauge, and filling the gauge with water had little effect on the magnitude of the pressure pulse. The volume of gas in the system was determined by venting the column while under pressure and measuring the water expelled. With the gauge filled with water, the total volume of water ejected when the system was vented was less than two drops. This means that even in the case of a major equipment failure, there would be no explosion or spewing of solution. 
Two resin columns were used, one a glass column $0.62 \mathrm{~cm}^{2}$ in cross section by $50 \mathrm{~cm}$ long and the other a stainless steel column $0.34 \mathrm{~cm}^{2}$ in cross section by $150 \mathrm{~cm}$ long. Both were jacketed so that the column could be heated with recirculating water. The glass column was used at pressures up to its rated operating pressure of 800 psi. This column was loaded with approximately $26 \mathrm{ml}$ of resin to give a bed $42 \mathrm{~cm}$ long. The stainless steel column was made from standard $3 / 8-$ in. tubing. It was loaded with approximately $50 \mathrm{ml}$ of resin, with two slightly different resin volumes being used. The resin was retained at the bottom with a $G$ porosity stainless steel frit pressed into a 3/8-in. to $1 / 8-i n$. tubing coupling. This column was used at pressures in excess of 2000 psi without difficulty.

Loading tests were made with a 1 -in.-long column made of 1/4-in. stainless. steel tubing. The column contained approximately $0.4 . \mathrm{ml}$ of resin in a bed 2.3 $\mathrm{cm}$ deep.

\section{Rengents}

All experiments were done with Dowex 50-X12 resin that had been hydraulically graded to approximately $15-$ to $20-\mu$ size or to $20-$ to $40-\mu$ size. Loading tests were carried out with the 15 to $20-\mu$ resin and also a similar resin of 3-10.18- $\mu$ size range, mostly in the larger end of the range.

Standard neodymium and praseodymium solutions were made up by dissolving neodymium oxide in nitric acid and praseodymium nitrate in water. The two resulting solutions contained $99 \mathrm{mg} \mathrm{Nd} / \mathrm{ml}$ and $70 \mathrm{mg} \mathrm{Pr} / \mathrm{ml}$, and both were adjusted to $\mathrm{pH} 2$. With few exceptions, the columns were loaded with either $1 \mathrm{ml}$ of each solution or with $0.25 \mathrm{ml}$ of each, giving total rare earth loadings of 169 and $42 \mathrm{mg}$, respectively.

All elutions were made with a-hydroxyisobutyric acid buffer solutions made by dissolving a weighed amount of the commercial acid in water, diluting to near the final volume, adjusting to the desired $\mathrm{pH}$ with ammonium hydroxide, and finally diluting to the final volume. Usually, fresh buffer was made for each elution to avoid. problems from molds, and as a result the concentration and $\mathrm{pH}$ did vary. slightly. from run to run. The distribution coefficients of the rare earths are very sensitive to the a-hydroxyisobutyrate ion concentration; so the elution curves did not exactly duplicate each other.

\section{Analyses}

Initially the rare earths were determined by emission spectrographic analysis, but this was rather slow and costly. for the numerous samples. Subsequently, concentrations were determined with a Cary Model 14 spectrophotometer. Praseodymium was determined by measuring the band at $444 \mathrm{m \mu}$ and neodymium by measuring the 
peak near $580 \mathrm{m \mu}$ if no praseodymium was present (praseodymium interferes to a small extent) or the peaks near 740 and $800 \mathrm{m \mu}$ if praseodymium was present. The limit of detection (0.002 absorbance) was equivalent to about $0.004 \mathrm{mg} / \mathrm{ml} \mathrm{for}$ neodymium and $0.008 \mathrm{mg} / \mathrm{ml}$ for praseodymium with a $5-\mathrm{cm}$ cell. Standard $5-\mathrm{cm}$ cells require about $15 \mathrm{ml}$ of solution, which was too much to permit good definition of the elution curves in most cases. Special cells were made which more closely match the dimensions of the light beam of the spectrophotometer than do cylindrical cells. These cells held $4 \mathrm{ml}$ and proved to be quite satisfactory.

All the neodymium bands are complex, being composed of several overlapping bands, and some of them are quite sensitive to the composition of the solution. There was a great difference in the spectra in nitrate solutions and in the a-hydroxyisobutyrate buffers, for example, and a smaller but significant dependence of the absorption at about $580 \mathrm{m \mu}$ on the buffer concentration. Usually.standards were run with each:buffer. Generally, material balances were within $3 \%$, and practically all were within $10 \%$. Material balance errors of several percent could result from misreading the volumes of the numerous samples.

\section{RESULTS AND DISCUSSION}

More than thirty elutions have been made. Conditions included $80^{\circ} \mathrm{C}$ and room temperature $\left(25^{\circ}\right)$, flow rates from $0.18 \mathrm{ml} / \mathrm{min}$ to $10 \mathrm{ml} / \mathrm{min}\left(0.5\right.$ to $\left.29 \mathrm{ml} \mathrm{cm}^{-2} \mathrm{~min}^{-1}\right)$, a-hydroxyisobutyric acid buffer concentrations from 0.3 to $0.8 \mathrm{M}, \mathrm{pH}$ from 4.0 to 4.8 , and rare earth charges of from 43 to $845 \mathrm{mg}$. It should be emphasized that these were not tracer experiments; the smallest amount of rare earths used was sufficient to completely load about $1 / 3 \mathrm{ml}$ of resin.

Typical elution curves are shown in Figs. 2 through 8 . The most obvious characteristic of all these elution curves is the unsymmetrical shape. In every case there is a relatively slow increase in concentration of the rare earth eluting, and (except in Fig. 4) this part of the curve is nearly linear. After the peák, there is a very rapid decrease in concentration. that approaches the behavior observed in experiments with tracer amounts of material. Thus, the shape of these curves is very different from the nearly.symmetrical Gaussian curves of tracer level experiment and opposite to the commonly encountered steep rise followed by tailing.

\section{Effect of Rare Earth Loading}

The effect of loading is shown by comparison of Figs. 2, 3, and 4. The curves in Figs. 2 and 3 are representative of most of the runs; conditions are identical except for loading, 43 and $201 \mathrm{mg}$. In both cases the neodymium begins to come off after the sume volume of eluent has passed through the resin, and the neodymium 
ORNL DWG $67-3656$

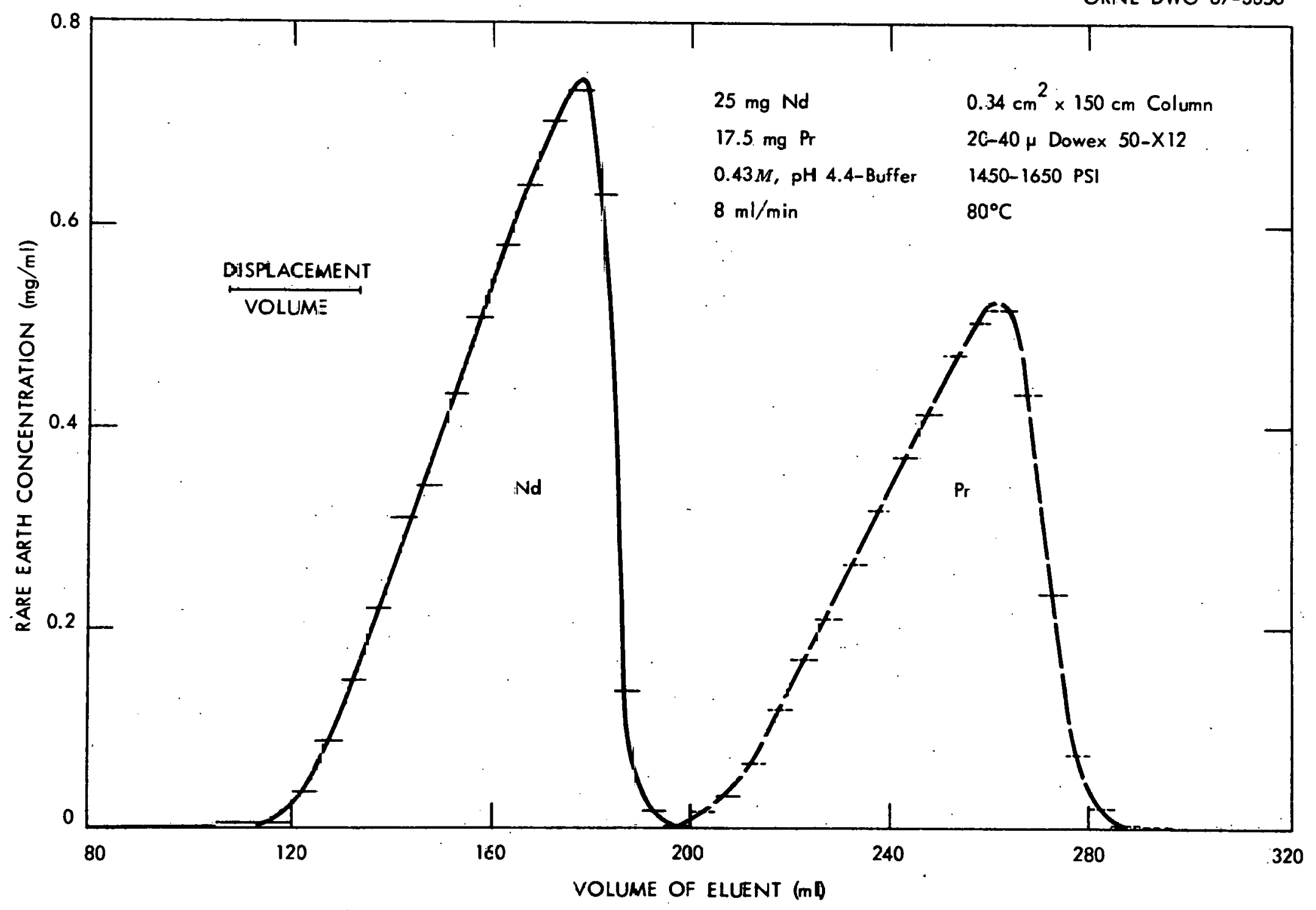

Fig. 2. Quartitative Nd-P-Separation is Obtained at High Flow Rate (23.5 $\mathrm{ml} \mathrm{crr}^{-2} \mathrm{~min}^{-1}$ ). 


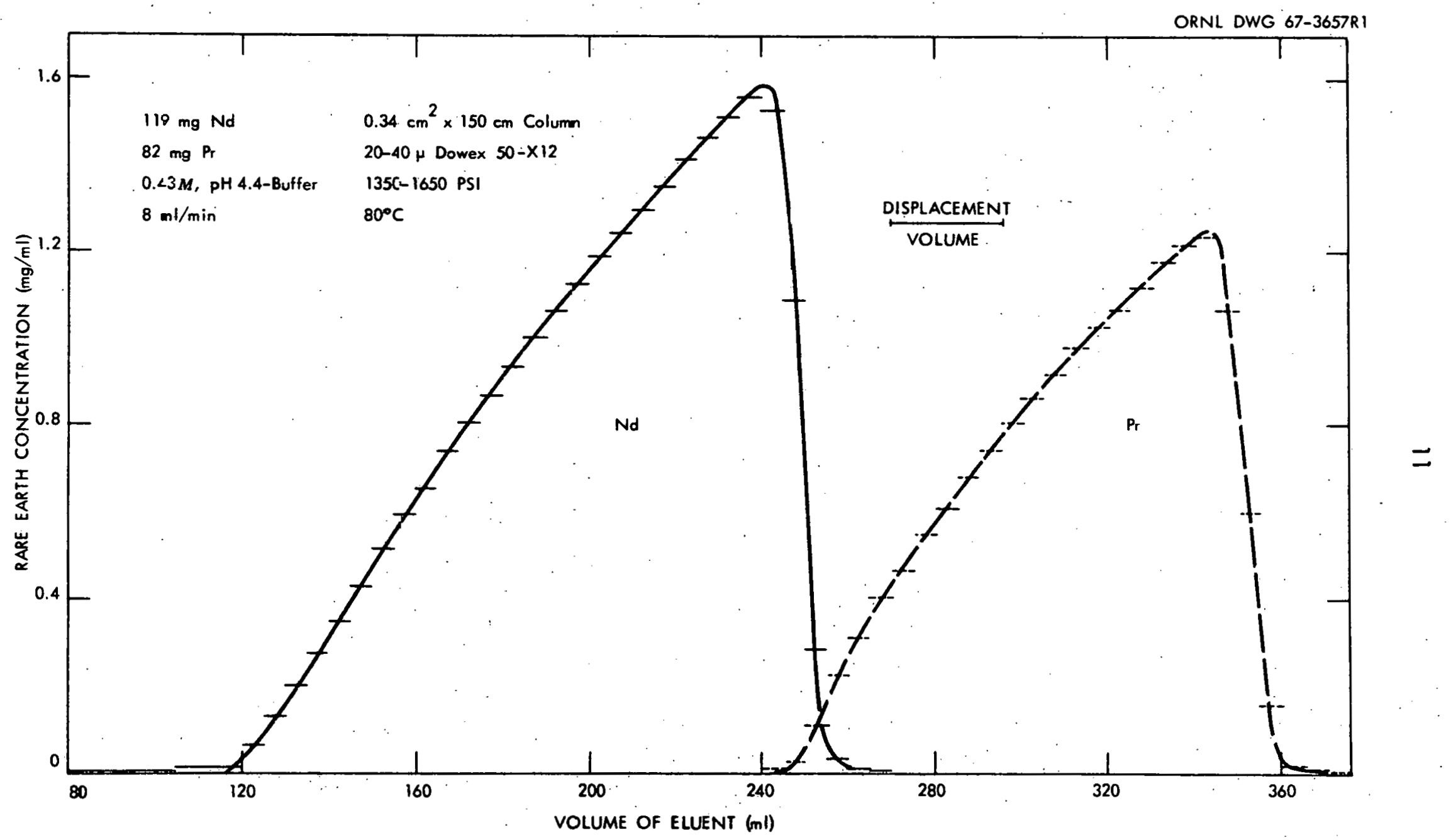

Fig. 3. Increased Rare Earth Loading (4\% of Resin) Results in Decreased But Still Good Separation. 


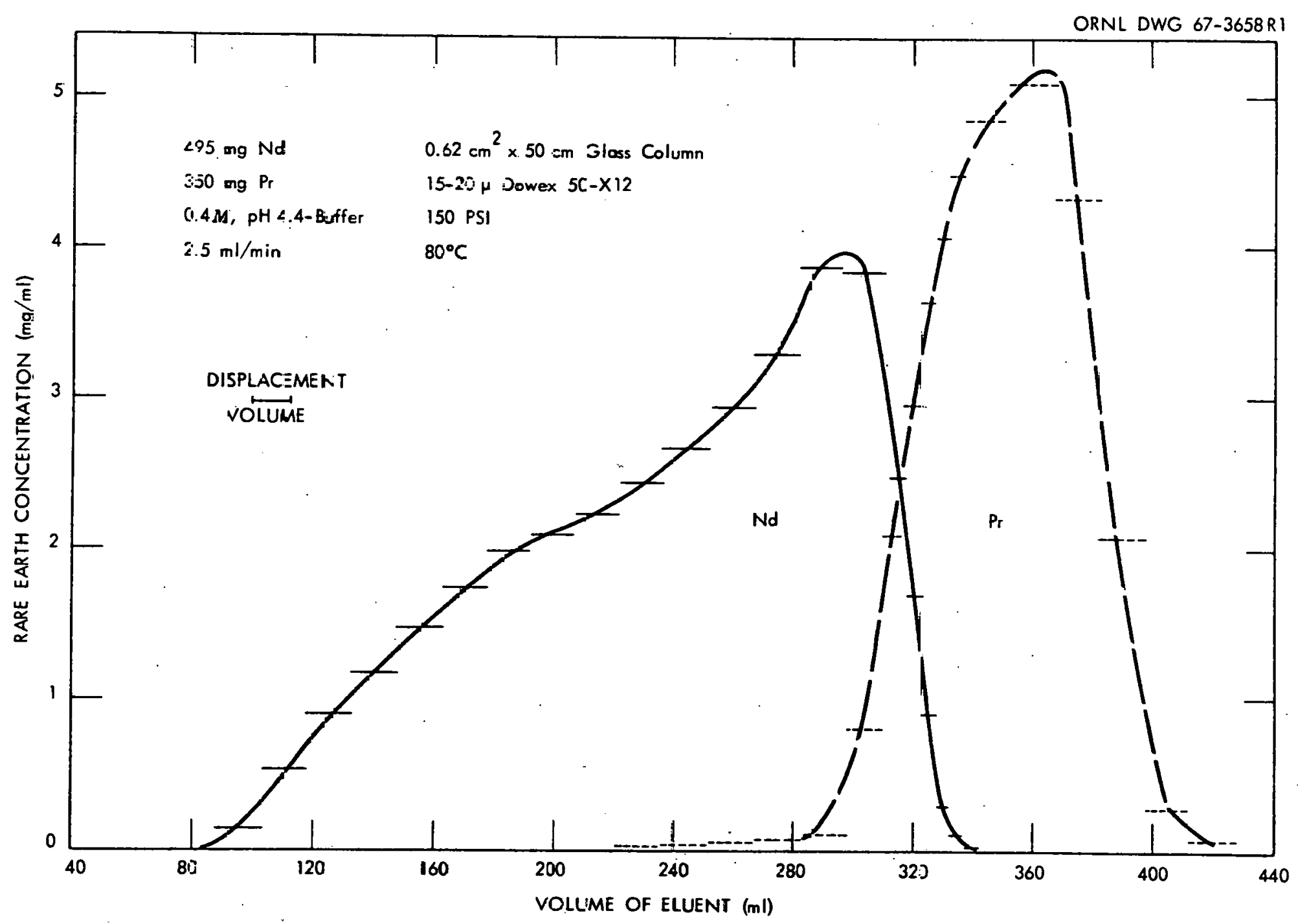

Fig. 4. Very High Resin Loading (25\%) Causes Change in Band Shape and Poorer Separation. 
concentration increases at about the same rate. As soon as nearly all the neodymium is off the column, the concentration drops abruptly, and of course this happens sooner with the smaller loading. Subsequently, the praseodymium starts coming off. The praseodymium band is displaced to the right as the column loading is increased (Fig. 3 vs Fig. 2). The shape of the praseodymium elution band is essentially the same as that for neodymium, with the nearly linear increase to a peak followed by an abrupt drop. Separation was quantitative within analytical limits with the smaller loading (Fig. 2)。 With the larger loading, there was some overlap of elution peaks, but more than $99 \%$ of each rare earth was obtained with less than $1 \%$ of the other as impurity. Separation can be improved by using a more dilute buffer or lower $\mathrm{pH}$ to displace the bands to the right.

The $845 \mathrm{mg}$ loading (Fig. 4) was on the smaller and shorter column and corresponds to about a $25 \%$ :loading of the resin. Conditions (listed on the figure) are different than for Figs. 2 and 3. Although there was substantial tailing of the bands, a fairly good separation of the bulk of the material was obtained. The odd shape of the bands, especially the neodymium, is believed to be the result of rare earth precipitation in the column. The solubilities of the rare earths in a-hydroxyisobutyrate solutions are generally a few (less than 10) milligrams per milliliter. The rare earth concentrations were substantially higher than this during the elution. Precipitation could have occurred also in most of the other runs when the saturated resin is first eluted, but any: such effect was less apparent than in this case.

\section{Effect of Flow Rate}

The small effect of flow rate is shown by comparing Fig. 5, in which the rate was $0.18 \mathrm{ml} / \mathrm{min}\left(0.53 \mathrm{ml} \mathrm{cm}^{-2} \mathrm{~min}^{-1}\right)$, with Fig. 2 , in which it was $8 \mathrm{ml} / \mathrm{min}(23.5$ $\mathrm{ml} \mathrm{cm}-2 \mathrm{~min}^{-1}$ ). Other conditions were the same except for a somewhat higher loading in Fig. 5. The elution bands were slightly broader and hence slightly less well separated at the faster flow. A run identical to that of Fig. 5, except that the flow rate was $1 \mathrm{ml} / \mathrm{min}$, gave an elution curve that could be superimposed on Fig. 5 . The highest flow rate studied was $10 \mathrm{ml} / \min \left(29.4 \mathrm{ml} \mathrm{cm}^{-2} \mathrm{~min}^{-1}\right)$, and this gave curves similar to Fig. 2 but displaced because a different eluent concentration was used. The entire elution at these high flow rates requires about $1 / 2 \mathrm{hr}$. The actual velocity of the eluent down the column is the order of $60 \mathrm{~cm} / \mathrm{min}$. If such rates can be maintained with scaled down columns for tracer separations, elutions with complete separation should be possible in a few seconds.

It was anticipated that with increasing flow rate a point would be reached at which the bands would broaden and begin to show some tailing, and this is beginning to happen in the elution shown in Fig. 2, as compared to Fig. 5. The rate limiting step causing these effects is not known, but it may result from a chemical reaction, from one of the diffusion processes, or perhaps something else. One purpose of this work was to determine how high a flow rate could be used, and it appears that the limit was approached for this system under the conditions of Fig. 2. 


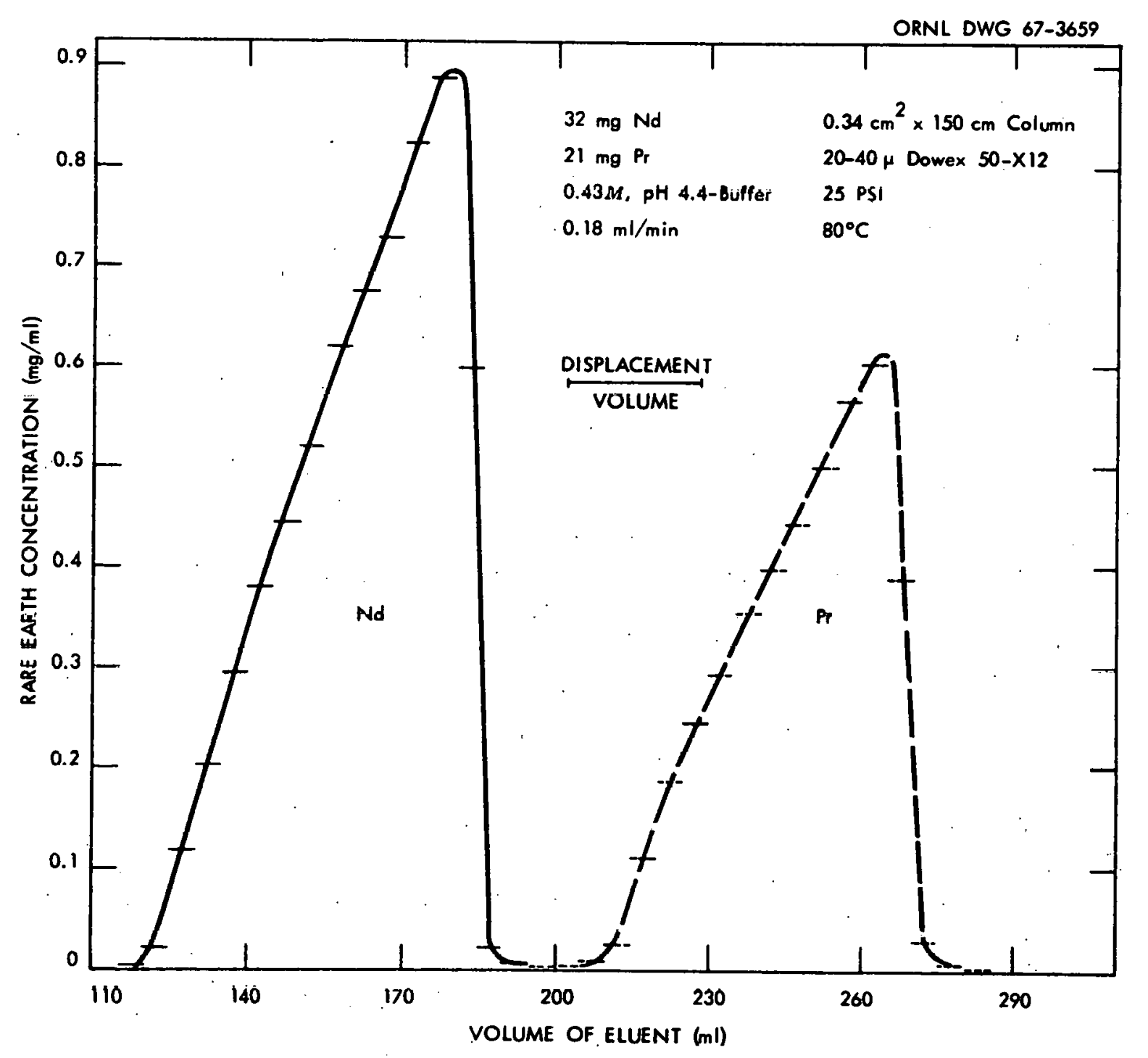

Fig. 5. Slightly Sharper Elution Bands are Obtained at Low Flow Rates. 
It should be pointed out, however, that a quantitative separation was still achieved in this experiment, with a flow rate of $23.5 \mathrm{ml} \mathrm{cm}^{-2} \mathrm{~min}^{-1}$ using 20- to $40-\mu$ resin.

Since the eluent was initially at room temperature in these runs and the column was surrounded by $80^{\circ} \mathrm{C}$ water, and since there is relatively little radial mixing of flow in a packed column such as this, it was thought that at the higher flow rates a temperature gradient might exist across the column and along an appreciable length near the top, with the center colder than the outer portion. At lower temperatures the flow rate is lower with a given pressure drop, and the distribution coefficient is also:lower. These two factors might partially compensate each other, but a local preponderance of either would lead to' some broadening of the elution bands. Hence, a preheater was installed in the line just before the column in the runs shown in Figs. 2 and 3. In earlier runs without the preheater there appeared to be somewhat more broadening of the bands, but the effect was not particularly significant.

\section{Effect of Temperature}

In order to gain some insight into the rate-controlling mechanism, an elution similar to that of Fig. 2 was made at room temperature. This run also differed in that the flow rate was decreased a factor of two (to $4 \mathrm{ml} / \mathrm{min}$ ) because of the higher pressure drop at lower temperatures, and that the eluent concentration was reduced to compensate for the decrease in distribution coefficient at the lower temperature. The resulting elution curve: (Fig. 6 ) is similar to Fig. 2, but may show somewhat more broadening on the right side of the bands. The important point is that the change is only slight in spite of $a 55^{\circ} \mathrm{C}$ decrease in temperature. Since the rate determining step is not greatly affected by temperature, it has a small activation energy. This suggests that the rate might very well be controlled by a diffusion process.

The results of elutions made at room temperature $\left(25^{\circ} \mathrm{C}\right)$ were essentially the same as those at $80^{\circ}$, except that the rare earths came off in one-fourth the volume with the same buffer concentration (compare Fig. 6 with Fig.7). This offers the possibility of temperature programming as well as concentration or $\mathrm{pH}$ programming to give a gradient elution. However, the greater pressure drop across the column at room temperature vs. $80^{\circ}$, or decrease in flow rate by approximately a factor of two for a constant pressure drop, provides a practical incentive to operate at elevated temperatures in that one may use higher flow rates, finer resin, or longer columns within the acceptable pressure drop.

\section{Effect of Eluent Concentration}

The effect of eluent concentration is indicated by comparing Fig. 7 with Figs. 2 to 5 . In order to demonstrate complete separation of neodymium and praseodymium, two elutions (one shown in Fig. 7) were made at $80^{\circ}$ with $0.30 \mathrm{M}$ buffer solution at 


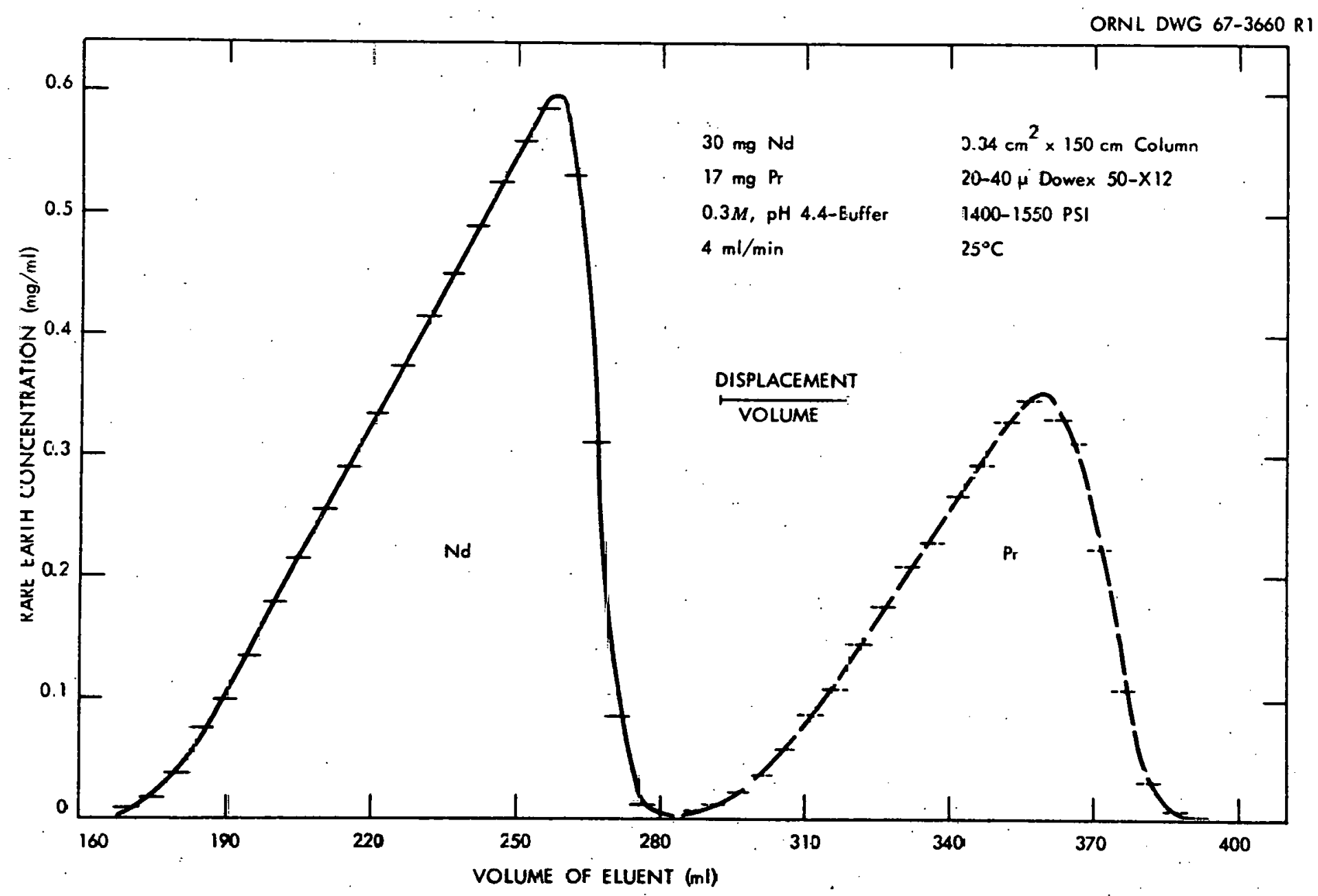

Fig. 6. Operation at $25^{\circ} \mathrm{C}$ Instead of $80^{\circ}$ Causes Only Slight Broadening of Elution Bands. 


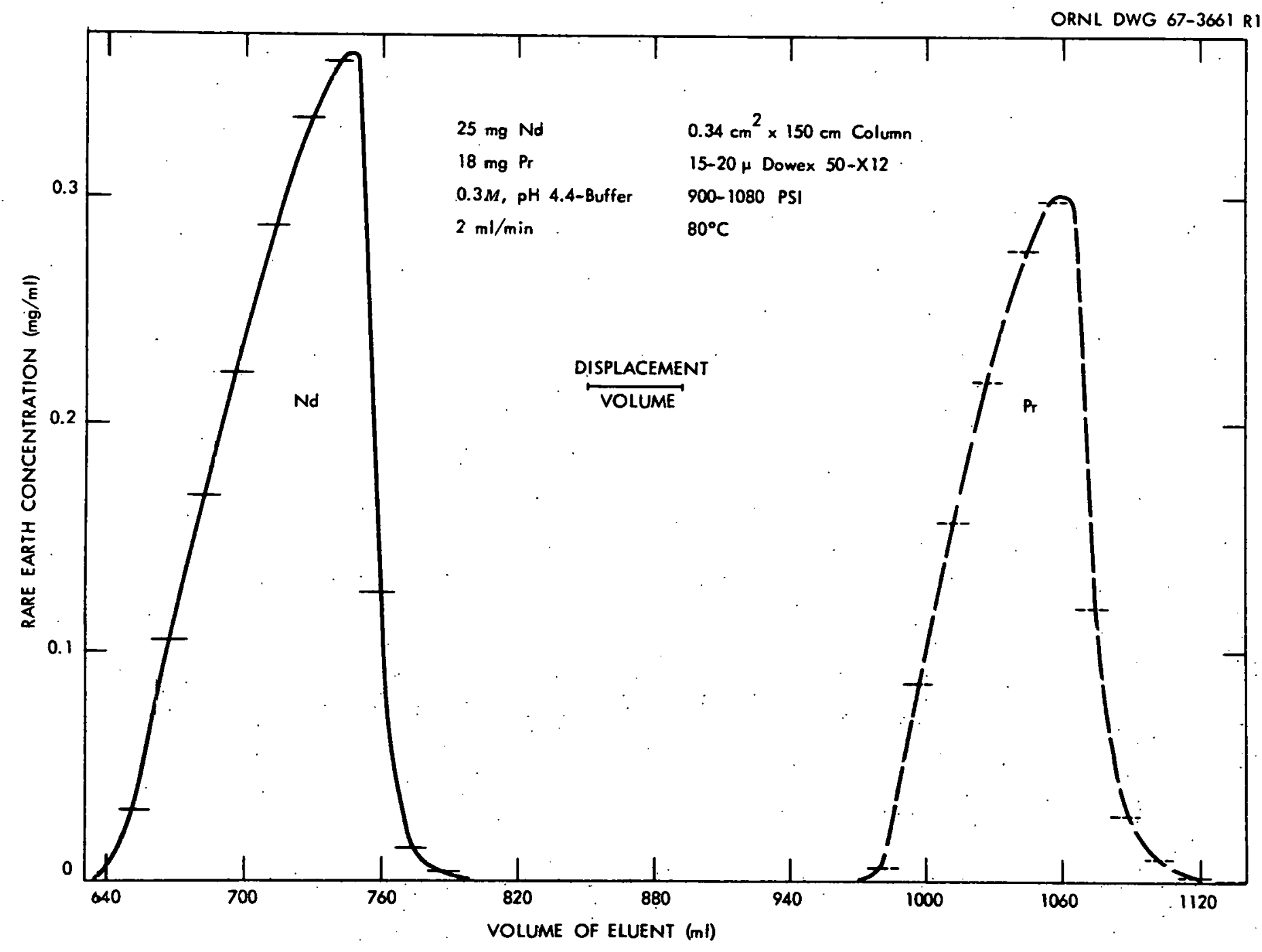

Fig. 7. Lower Eluent Concentration Yields Elution Bands that are Widely Separated and Still Sharp. 
$\mathrm{pH} \mathrm{4.4;} \mathrm{this} \mathrm{required} \mathrm{a} \mathrm{much} \mathrm{larger} \mathrm{volume} \mathrm{than} \mathrm{of} 0.43 \mathrm{M}$ buffer solution before the rare earths came off the column. Neodymium came off after 31 displacement volumes, praseodymium after 44 , and there were seven displacement volumes between the two bands in which no rare earth could be detected. Elutions with still more concentrated buffer solutions (to $0.8 \mathrm{M}$ ) resulted in the bands coming off very quickly; a fair degree of separation was obtained even when neodymium came off in the second volume change, even though the cuts were relatively so large that the curves could not be defined very well.

One elution was made with a $0.37 \mathrm{M}$ a-hydroxisobutyrate buffer of $\mathrm{pH} 4.4$ containing also $0.30 \mathrm{M}$ ammonium nitrate to study the effect of the increased ammonium ion concentrafion (which competes with the rare earth for resin sites). Both the neodymium and praseodymium bands came off in approximately $18 \%$ of the volume that would be required for the same buffer without the ammonium nitrate, and the same separation factor was obtained. The actual separation was not so good since the neodymium started eluting after only two column volumes and there was insufficient volume for the bands to separate. However, this experiment indicates that if the cost of a-hydroxyisobutyric acid is a significant factor, the amount used can be substantially decreased by replacing some of it with an ammonium salt such as ammonium nitrate. In this case the elution bands corresponded to those expected for a $0.6 \mathrm{M}$ buffer of $\mathrm{pH} 4.4$.

\section{Effect of Column Orientation}

Since we plan to operate these columns in glove boxes and hot cells, some tests were made with the column mounted horizontally and at a $20^{\circ}$ inclination. Standard glove boxes are longer than they are high, so that a horizontal or oblique column could be longer. These runs were made at room temperature. The first run with the column in a horizontal position did give a different shape for the elution curve (Fig. 8), which could have been caused by the top of the resin bed falling over. The top of the bed was reformed with the column vertical and a run was made with the column tilted $20^{\circ}$ above horizontal (the maximum allowed in a 6-ft glove box). This run was completely normal. Subsequently, sand was poured on the top of the resin bed to hold it in place, and a final run was made with the column horizontal. This run also gave a normal elution curve, but the pressure drop across the column was rather erratic and surprisingly low. Although satisfactory operation was obtained with the horizontal column, there are some uncertainties of operation that require further attention.

\section{Louding Tésts}

One of the serious problems with high-radiation level separations is radiation damage to the resin, which occurs largely during the loading step as a high concentration builds up at the top of the column. A few loading tests were made with fine 


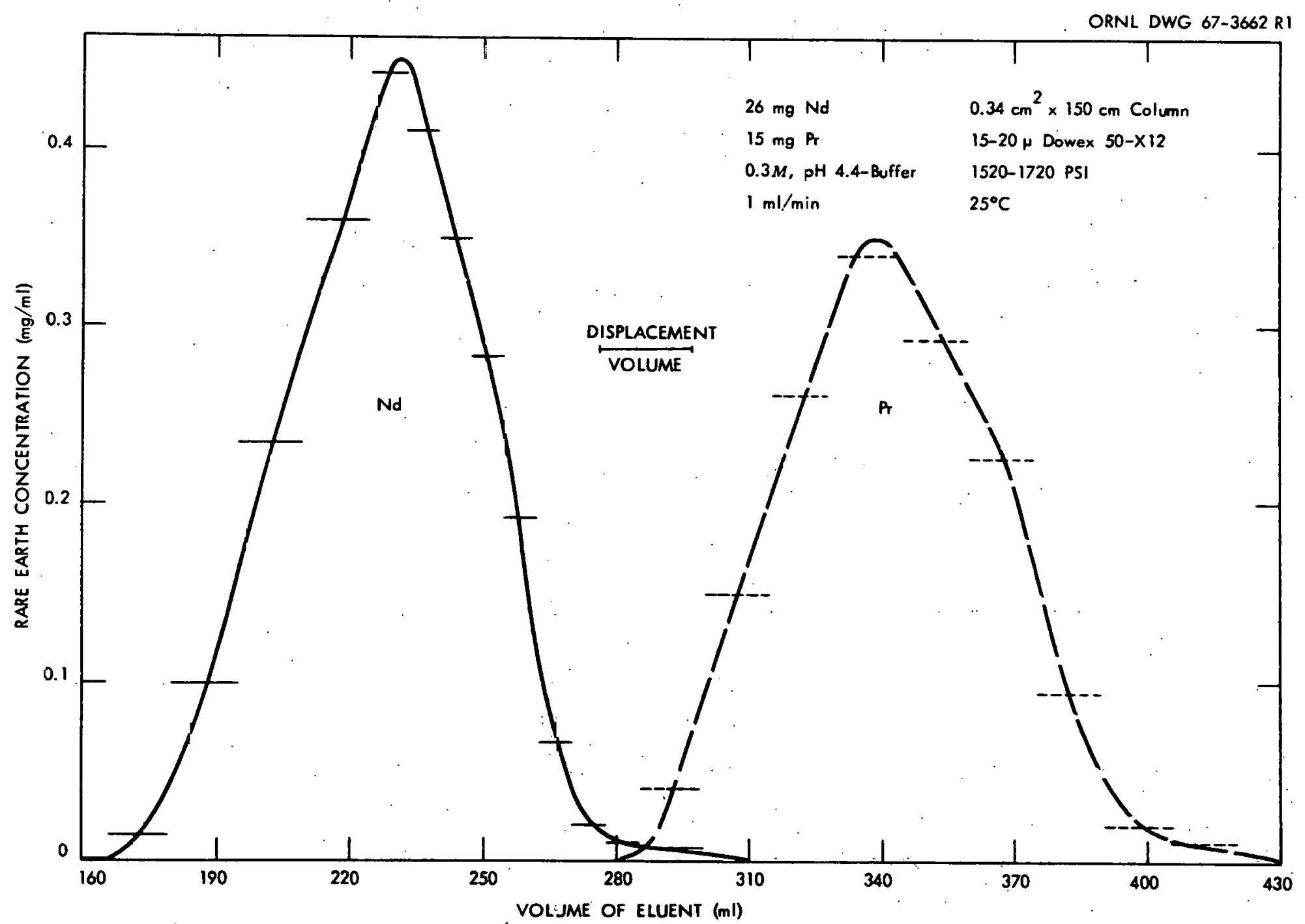

Fig. 8. Separation is Satisfactory with Column Mounted Horizontally. 
resin and high flow rates in order to determine the feasibility of decreasing this time. Although a sharp loading certainly eases the separation problem in a chromatographic elution, the preceding results show that any desired degree of separation of neodymium and praseodymium can be obtained by proper choice of elution conditions. Therefore, one might be justified in accepting a poorer loading if a significant decrease in loading time can be accomplished. Also, one would expect the use of fine particle resin to compensate to some extent for higher flow rates, so that reasonably sharp loadings could still be obtained.

The small column with a resin bed $0.17 \mathrm{~cm}^{2}$ in area by $2.3 \mathrm{~cm}$ long was loaded by pumping a neodymium solution through it at flow rates up to $8 \mathrm{ml} / \mathrm{min}$, and the effluent was collected in approximately $4 \mathrm{ml}$ cuts which were subsequently analyzed. The feed solutions contained $2 \mathrm{mg} / \mathrm{ml}$ of neodymium in $0.05 \mathrm{M}$ nitric acid, $0.25 \mathrm{M}$ nitric acid, or $2 \mathrm{M}$ formic acid adjusted to $\mathrm{pH} 3$ with ammonium hydroxide. Typical loading curves are shown in Fig. 9. In general, there was no detectable neodymium in the effluent until the column was loaded to about $60 \%$ of its capacity for 15 to $20-\mu$ resin, and to about 75 to $80 \%$ of its capacity for 3 to $18-\mu$ resin. The breakthrough curve was $S$-shaped in all cases. It was somewhat steeper, and started slightly later, at lower flow rates and with the more dilute nitric acid solution, but these factors did not cause any great variation. Flow rates ranged from 28 to $50 \mathrm{ml} \mathrm{cm}^{-2}$ $\mathrm{min}^{-1}$. In order to clearly demonstrate any effect of flow rate, a wider range would have to be covered. In these tests the factor which had the largest effect was resin size or possibly variation in uniformity of packing of the resin.

The purpose of these tests was to show that resin could be satisfactorily loaded at very high flow rates, as compared with those normally used; and this was shown. For example, with the 3 to $18-\mu$ resin and a flow rate of $4.2 \mathrm{ml} / \mathrm{min}$, the resin was loaded to more than $75 \%$ of capacity before neodymium was detected in the effluent, and to $80 \%$ of capacity when the effluent concentration reached $0.1 \mathrm{mg} / \mathrm{ml}(5 \%$ of feed). One might estimate from this that approximately one-fifth the amount of resin used is capable of loading neodymium quantitatively under these conditions. This would correspond to a bed depth of less than $5 \mathrm{~mm}$, or a residence time for the solution in the bed of approximately one-half second. It is clear that substantial loadings of around $100 \mathrm{mg}$ rare earths per $\mathrm{ml}$ of resin can be made on quite small columns at high flow rates of about $50 \mathrm{ml} \mathrm{cm}-2 \mathrm{~min}^{-1}$.

Only one test has been made with the $2 \mathrm{M}$ formate solution of $\mathrm{pH} 3$. The neodymium broke through sooner than from nitrate solutions, but generally similar loading characteristics were observed. The formate is of interest since it may permit a smaller volume of feed in practical situations. In conventional actinide processing the metals are precipitated with ammonia and the precipitate is dissolved in a small volume (depending on the experimental equipment) of several molar acid; this must be diluted to permit good loading on the resin column, yielding a substantial increase in feed volume. We have observed that rare earth hydroxide precipitates dibsolve readily in formic acid solutions ( $2 M$ for example) and that very 


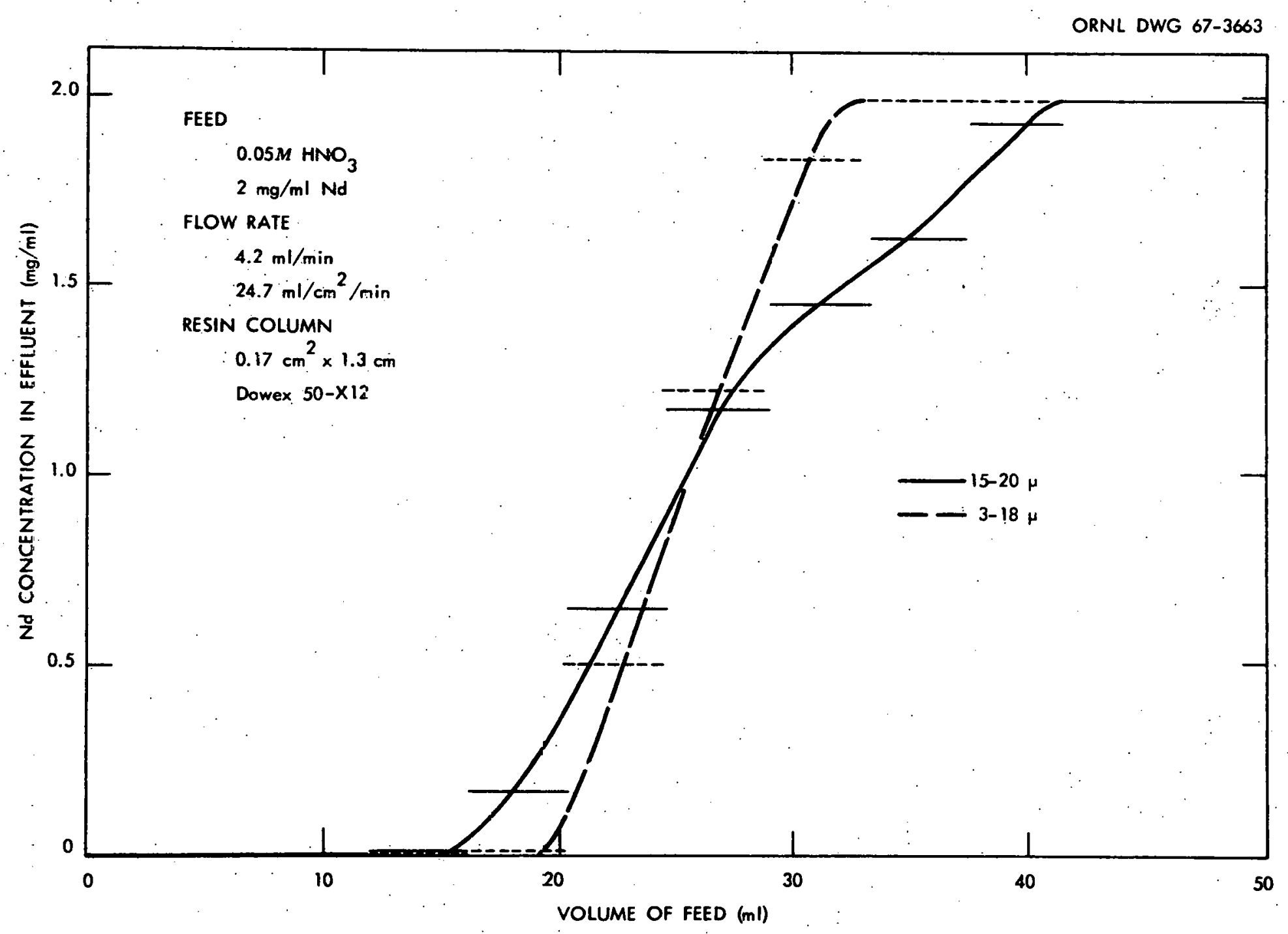

Fig. 9. Fine Resin Improves Sharpriess of Loading at High Flow Rates. 
high distribution coefficients are obtained from such solutions, even from rather concentrated formic acid. Thus, it may not be necessary to dilute the dissolver solution before loading the column. In some cases, rare earths have precipitated from the formic acid solution after standing several days.

Erratic pressure drops were observed at high flow rates with the smaller resin. This might be the result of very small resin beads plugging some of the larger pores of the stainless steel frit that supports the bed. This was observed only with the 3 to $18-\mu$ resin when operating initially at about 1000 psi. A frit with more uniform and smaller holes will be used subsequently.

No attempt has been made to optimize the loading procedure at this time, but several possibilities are suggested by these results. Clearly, the resin should be quite small. The column should be very short, but pressure drop will still put a lower limit on the resin size. Flow rates of the order of $50 \mathrm{ml} \mathrm{cm}^{-2} \mathrm{~min}^{-1}$ appear entirely practical; the flow rate could be decreased during the last 20 to $30 \%$ of the loading to give a somewhat sharper band if desired. There must be a compromise between length and cross section of the column and the resin particle size so that the pressure drop at the desired flow rate is permissible. After loading, the column may be eluted at a lower flow rate through a long chromatographic column which would probably contain somewhat coarser resin. If radiation damage is really limiting, the elution (especially the first part) may be carried out at a high flow rate also, thus moving the bands down the column quickly.

\section{PLANS FOR ADDITIONAL WORK}

Some cold work with rare earths will be continued, primarily to study the effects of further variation of conditions and to study different resins (for example Dowex 50-X4), different systems (such as anion resin-salt solutions), and perhaps extraction chromatography. This system offers promise for the latter since the use of a very small sized support medium yields a much larger surface grea, and therefore a greater amount of the second phase per unit volume.

Work will be started very soon in glove boxes, and a set of smaller columns is being fabricated for this. Initially, we plan to study the americium-curium separation to determine the effect of lower loadings (analytical limitations with stable rare earths require appreciable loadings), to gain more information about tailing of the first band into the second at a low concentration, and to see how rapid a separation can be made from small columns and low loadings such as are encountered in many applications at near tracer levels. We also plan to attempt the separation of all the trivalent elements in a small sample of TRU dissolver solution; this is potentially a very useful analytical tool. 
Columns have also been designed for installation in a hot cell, and these will be used in a short time for a californium-einsteinium separation. Subsequently these columns will be used for some of the numerous separation problems that exist in the transplutonium element processing work at ORNL. No scale-up. is required since the scale of this work exceeds that required in transcurium elements during the next few years. We also plan to load and elute sufficient ${ }^{242} \mathrm{Cm}$ to determine the performance of the column under conditions which have caused operational problems in the past by radiolytic gassing and radiation damage to the resin.

It is again emphasized that this work is preliminary and incomplete, and it is being reported at this time because of the interest it has attracted from various sources. This system is applicable to a wide variety of separation problems, and numerous uses for. it may be foreseen. 


\section{REFERENCES}

I. S. G. Thompson, B. G. Harvey, G. R. Choppin, and G. T. Seaborg, J. Am. Chem. Soc., 76, 6229 (1954).

2. G. R. Choppin, B. G. Harvey; and S. G. Thompson, J. Inorg. Nucl. Chem。, 2, 66 (1956).

3. G. R. Choppin and B. G. Harvey, lbid., 3, 153 (1956).

4. H. L. Smith and. D. C. Hoffman, lbid., 3, 243 (1956).

5. Chem. Techmul. Div. Ami. Proj. Rept. May 31, 1961; ORNL-3627, pp. 124, 138.

6. J. Fuger, J. Inorg. Nucl. Chem., $\underline{5}, 332$ (1958).

7. J. Fuger, Ibid., 18, 263 (1961).

8. Y. Marcus and F. Nelson, J. Phys. Chem., 63, 77 (1959).

9. S. Adar, R. K. Sjoblom, R. F. Barnes, P. R. Fields, E. K. Hulet, and H. D. Wilson, J. Inorg. Nucl. Chem. 25, 447 (1963).

10. Y. Marcus, M. Given, and G. R. Choppin, Ibid。, 25, 1457 (1963).

11. W. Kraak and W. A. Van Der Heijden, Ibid., 28, 221 (1966).

12. E. P. Horwitz, K. A. Orlandini, and C. A. A. Bloomquist, Inorg. Nucl. Chem., Letters, 2,87 (1966).

13. E. Cerrai, Chromatographic Reviews, 6, 129 (1964).

14. J. Kooi, Radiochemica Acta, 5 , 91 (1966).

15. Chem. Technol. Div. Ann. Prog. Rept. May 31, 1965, ORNL-3830, p. 166.

16. Chem. Technol. Div. Ann. Prog. Rept. May 31, 1966, ORNL-3945, p. 116.

17. Ibid., ORNL-3945, p. 205. 


\section{INTERNAL DISTRIBUTION}

1. E. D. Arnold

2. R. D. Baybarz

3. J. E. Bigelow

4. R. E. Blanco

5. R, E. Brooksbank

6. K. B. Brown

7. W. D. Burch

8-12. S. R. Buxton

13-18. D. O. Campbell

19. C. F. Coleman

20. D. J. Crouse

21. F. L. Culler

22. D. E. Ferguson

23. L. M. Ferris

24. H. E. Goeller
25. T. H. Handley

26. L. J. King

27. R. E. Leuze

28. M. H. Lloyd

29. F. L. Moore

30. A. D. Ryon

31. W. E. Unger

32. R. G. Wymer

33-34. Central Research Library

35. Document Reference Section

36-38. Laboratory Records Department

39. Laboratory Records - (RC)

40. ORNL Patent Office

41-56. DTIE

57. Research and Development

Division - ORO

\section{EXTERNAL DISTRIBUTION}

58. P. R. Fields, Argonne National Laboratory

59. S. M. Fried, Argonne National Laboratory

60. E. P. Horwitz, Argonne. National Laboratory

61. R. A. Pennemann, Los Alamos Scientific Laboratory

62. L. B. Asprey, Los Alamos Scientific Laboratory

63. R. W. Hoff, Lawrence Radiation Laboratory, Livermore

64. F. K. Hulet, Lawrence Radiation Laborntory, Livermore

65. R. G. Morrow, Lawrence Radiation Laboratory, Livermore

66. M. S. Coops, Lawrence Radiation Laboratory, Livermore

67. T. Parsons, Lawrence Radiation Laboratory, Berkeley

68. Harry Groh, E. I. du Pont de Nemours \& Company, SR

69. Carl Schlea, E. I. du Pont de Nemours \& Company, SR

70. J. E. Powell, Ames Laboratory

71. E. J. Wheelwright, Battelle Northwest, Richland 